\title{
NOTAS SOBRE A CRÍTICA DE NIETZSCHE À FILOLOGIA E À EDUCAÇÃO
}

\author{
NOTES ON NIETZSCHE'S CRITICISM OF PHILOLOGY AND EDUCATION
}

\author{
TEREZA C CALOMENI ${ }^{1}$ \\ Universidade Federal Fluminense (UFF) - Brasil \\ terezaccalomeni@gmail.com
}

\begin{abstract}
RESUMO: Vinculado ao projeto de pesquisa A singularidade do trágico-dionisíaco e a crítica da cultura no jovem Nietzsche, o artigo aborda alguns aspectos da crítica nietzschiana da filologia alemã como ponto de partida para uma reflexão posterior sobre a relação, estabelecida por Nietzsche, entre cultura e educação. Retomando as ideias filológicas de $O$ nascimento da tragédia e a polêmica ulterior à sua publicação, o texto acolhe a hipótese de que a crítica à filologia - e à história -- pode ser compreendida como parte de sua crítica a uma determinada concepção de ciência e, em especial, ao ensino alemão de seu tempo, fortemente marcado pelo espírito histórico e cientificista.
\end{abstract}

PALAVRAS-CHAVE: Nietzsche. Cultura. Educação. Filologia.

ABSTRACT: Related to the project of research, The singularity of the tragic-dionysian, and the criticism of culture in the young Nietzsche, the article discusses some aspects of the Nietzschean critique of german philology as a starting point for a later reflection on the relation established by Nietzsche between culture and education. Taking up the philological ideas of The birth of tragedy and the controversy subsequent to its publication, the text accepts the hypothesis that the critique of philology - and history - can be understood as part of its critique of a certain conception of science and, in particular, the German teaching of his time, strongly marked by the historical and scientific spirit.

KEYWORDS: Nietzsche. Culture. Education. Phylology.

"Quero ser mais que um instrutor de bons filólogos. Penso nos deveres dos mestres de hoje: preocupo-me com a geração que

vem depois de nós" (Nietzsche)

I

Entre biógrafos e comentadores é frequente a indicação de que, em meados dos anos 1860 e no início da década seguinte, cresce o interesse de Nietzsche pela cultura e arte gregas, em particular, pela tragédia. Três são as três razões principais:

${ }^{1}$ Professora da Universidade Federal Fluminense (UFF). 
a leitura, no outono de 1865, da obra de Schopenhauer, O mundo como vontade e representação; a forte impressão causada pelo curso História da tragédia grega e uma introdução aos "Sete contra Tebas", de Ésquilo, oferecido pelo helenista alemão Ritschl no inverno de 1865-1866, em Leipzig; a íntima e estelar amizade (NIETZSCHE, 2001, \ 279, Amizade estelar, p. 189.) com Wagner, tecida a partir de um primeiro encontro em 1868. Não por acaso, o jovem filólogo ingressa na pequena Universidade de Basileia em abril de 1869 e, a partir de então, como professor de filologia clássica, mantém vivo o franco desejo de remontar à cultura e à arte dos gregos, sobretudo para avaliar, criticamente, a cultura alemã de seu tempo. Não por acaso, importantes formulações de $O$ nascimento da tragédia a partir do espírito da música - escrito em 1871 e publicado no início de 1872 - são antecipadas em cursos ministrados na Universidade e no Pädagogium e em palestras, preleções e conferências, atividades obrigatórias ao intenso exercício da docência na academia suíça.

Em atenção a exigências acadêmicas, em 1870 - o segundo dos dez anos em que exerce o magistério -, Nietzsche escreve quatro textos que, bem próximos de estudos realizados em Leipzig, acabam por apoiar a redação do livro de 18711872 e favorecer o amadurecimento de sua concepção da tragédia, a arte elevada pela qual o povo helênico celebrara a vida, a despeito da presença incontornável da dor e do sofrimento à existência humana: O drama musical grego, ${ }^{2}$ Sócrates e a Tragédia, ${ }^{3}$ Contribuição à história da tragédia grega. Introdução à tragédia de Sófocles ${ }^{4}$ e $A$ visão dionisíaca de mundo. ${ }^{5}$ Indícios de sua singularidade, tais escritos são, para pesquisadores de estética e da filosofia nietzschiana, um precioso testemunho da gestação de $O$ nascimento da tragédia. Nos quatro, vislumbra-se parte do movimento de construção do olhar nietzschiano para a Antiguidade e da original concepção de tragédia e, neste caso, das principais hipóteses do livro, exemplo da comunhão, para Nietzsche, fundamental à educação dos jovens, entre filologia, filosofia e arte. Nos quatros, encontram-se, pois, muitos dos temas tratados no livro de 1871.

Nesses textos, vislumbra-se também uma crítica dos limites da filologia, crítica já insinuada anteriormente em sua aula inaugural Homero e a filologia clássica, de 28 de maio de 1869. Àquela época, apesar de conservar uma inevitável proximidade com a tradição filológica e, portanto, não romper inteiramente com a filologia de seu tempo, Nietzsche já certificara seu distanciamento, inclusive ao assinalar, intempestivamente, o valor dessa relação entre filologia, filosofia e arte: por um lado, exigira gratidão à filologia e lembrara aos ouvintes que "sangue e suor e o mais penoso esforço intelectual de inúmeros jovens da nossa ciência foram necessários para fazer emergir aquele mundo de seu abismo" e que "a filologia vem a um mundo repleto de cores e imagens sombrias, repleto das mais profundas e incuráveis dores, e consola narrando a luminosa beleza dos deuses de um mundo mágico longínquo, azul, venturoso"; por outro, assegurara que "toda

\footnotetext{
${ }^{2}$ O drama musical grego, conferência pública proferida em 18 de janeiro de 1870.

3 Sócrates e a tragédia, conferência pública de $1^{\text {o }}$ de fevereiro de 1870.

${ }^{4}$ Preleção apresentada no verão de 1870, preparada em Desenvolvimento do drama grego, curso oferecido, em 1869, no Pädagogium, onde, no ano seguinte, Nietzsche lê As bacantes, de Eurípedes.

5 Texto finalizado em Maderanertal, entre final de julho e início de agosto.
} 
e qualquer atividade filológica deve ser abarcada e cercada por uma visão filosófica universal [philosophische Weltanschauung], na qual tudo que é particular e isolado seja dissipado, enquanto rejeitável, e apenas subsistam o todo e a uniformidade" (NIETZSCHE, 2006, p. 198).

Ousado, concebido à contracorrente das postulações primordiais da filologia da época, $O$ nascimento da tragédia não tem boa recepção no meio intelectual: contrariando a expectativa de que sua leitura do mundo antigo pudesse produzir bons frutos, acadêmicos atribuem ao livro um julgamento bastante diferente do que supõe Nietzsche. Polêmico, suscita tão grande perplexidade entre alguns filólogos que acaba por se tornar alvo fácil de críticas corrosivas. Precocemente extemporâneo, o professor Nietzsche - de quem evidentemente se espera o fortalecimento da filologia, considerada como ciência desde o início do século XIX com a iniciativa de Friedrich August Wolf6-, discorda de textos já publicados sobre a Antiguidade e a tragédia e, mais do que isto, desvia-se tanto do método e de princípios julgados imprescindíveis ao sucesso do empreendimento filológico quanto do estilo da filologia ensinada nas universidades alemãs. Ao refletir sobre a origem, a finalidade e a morte da tragédia ática e, por fim, apostar na possibilidade de renascimento do trágico extraviado da cultura pelo predomínio do "otimismo teórico" representado por Sócrates possibilidade, aos seus olhos, já presente à modernidade, na crítica de Kant à metafísica, na filosofia de Schopenhauer e, sobretudo, na arte de Wagner -, $O$ nascimento da tragédia, inovador, põe em cena uma filologia tão diversa que filólogos, assustados, ali não reconhecem seu ofício nem a Antiguidade por eles minuciosamente pesquisada. Sem dúvida, Nietzsche é devedor da filologia - a "ciência da Antiguidade" (Altertumswissenchaft) -, mas ainda assim, praticamente não utiliza os recursos habituais à atividade filológica, como a inclusão de notas e citações em grego, a remissão a comentadores, a referência à arqueologia, à morfologia e à etimologia, embora recorra a textos antigos e à mitologia.

Recusando-se a aderir à cega filologia de toupeiras que, submissa a procedimentos científico-metodológicos, se sustenta, em sua opinião, sobre uma visão restrita da Antiguidade, Nietzsche alia a filologia à filosofia e à arte, escapa à frieza do estilo acadêmico e, com uma sofisticada sensibilidade de filósofo, dilata o horizonte da investigação filológica. No seu entender, a filologia deve se envolver pela filosofia, sempre pronta a enriquecer a pesquisa e o discurso filológicos, ao invés de se atrelar, exclusiva e obsessivamente, ao ideal de captura da verdade ou de se subjugar, irremediavelmente, ao imperativo de reconstituição ou "explicação" objetiva - científica - do passado. É assim que, filólogo de formação, Nietzsche olha para o mundo antigo pelas lentes de uma filosofia moderna: as teses filológicas acerca do nascimento e da morte da tragédia implicam a consideração da filosofia de Schopenhauer.

\footnotetext{
${ }^{6}$ Friedrich August Wolf (1759-1824), reconhecido como criador da filologia.

${ }^{7}$ Carta a Erwin Rodhe, de 2 de novembro de 1968.
} 
Precocemente seduzido por indagações filosóficas, ${ }^{8}$ a intenção de reunir filologia e filosofia não é nova; ao contrário, acompanha Nietzsche desde Leipzig e ecoa, claramente, nas últimas linhas de sua primeira aula. $O$ nascimento da tragédia surpreende a comunidade acadêmica ao advogar em favor dessa aliança, tão alheia e inusitada à filologia semeada nas universidades da Alemanha e enaltecida pelo mundo "culto" de seu tempo, uma filologia bem distante do ideal de Bildung plenamente sedimentado na célebre Escola de Pforta, frequentada por ele entre 1858 e 1864; uma filologia bastante próxima do historicismo, aberta e veementemente rechaçado como excesso de "sentido histórico", dois anos depois, nas linhas da Segunda consideração extemporânea; sobre a utilidade e a desvantagem da história para a vida; uma filologia que, crente no poder e na competência da ciência e em defesa intransigente de sua autonomia e objetividade, autoriza a disjunção - tão perniciosa à educação dos jovens - entre conhecimento e vida. O nascimento da tragédia surpreende, então, por sua extemporaneidade, declarada, inclusive, por essa afirmação da necessidade de se amparar a filologia por uma visão filosófica. Nas mãos de Nietzsche, bem diferente do que pretendem os filólogos, a filologia não é aceita como conhecimento puro e imaculado ou como ciência autônoma, apta a "explicar" rigorosamente o passado longínquo. Em Nietzsche - esta talvez seja a maior objeção ao livro -, a visita aos gregos é artifício para uma reflexão sobre o presente e as promessas de futuro: "Não saberia que sentido teria a filologia clássica em nossa época senão o de atuar nela de maneira intempestiva - ou seja, contra o tempo e, com isso, no tempo e, esperemos, em favor de um tempo vindouro", diz mais tarde, em 1874, na Segunda extemporânea.

Como O nascimento da tragédia - especialmente essa decisão de ler a Antiguidade tomando como ponto partida uma filosofia moderna para pensar o presente - atinge em cheio a tão almejada autonomia da filologia, filólogos, indignados, porque fiéis ao método histórico e comprometidos com a exaltação do rigor científico e da objetividade, recolhem suas palavras como uma traição, um confronto indesejado e impertinente. O livro é admitido como uma leitura bem equivocada do mundo antigo e, pelo exame dos comentários a ele dirigidos, como uma espécie de afronta, arrogante e pretensiosa, de quem não sabe o que é filologia nem ciência. Presa à noção de ciência como "explicação" e convicta de que a imparcialidade é o grande requisito para se avistar com justiça o passado, a academia não pôde absorver o ideal nietzschiano de ampliação da filologia nem assimilar a abrangência da suspeição de suas supostas objetividade e autonomia. Afinal, envolver a filologia pela filosofia e pela arte não seria macular ou destruir sua especificidade?

\footnotetext{
${ }^{8}$ No inverno de 1870-1871, Nietzsche escreve a Rodhe: "Em relação à filologia, sinto-me cada vez mais distante, tendo por ela o maior desprezo que se possa imaginar. Tudo o que pudesse alcançar por esse lado - elogios, censuras, e até as mais altas glórias - me faz tremer de horror. Habituo-me progressivamente a viver como filósofo e já creio em mim."
} 
II

Escrito sob inspiração da música de Wagner e da filosofia de Schopenhauer e, até certo ponto, do pensamento de Kant, O nascimento da tragédia, um "tratado de estética" de certa forma "independente" de obras posteriores, é estruturado, basicamente, a partir de três propósitos primordiais: investigar a origem e a finalidade da tragédia grega ( $\$ 1-10)$, descrever a morte da tragédia pela filosofia de Sócrates e pela dramaturgia de Eurípedes ( $\$$ 11-15) e anunciar a volta do pathos trágico ( $(16-25)$ que, esquecido no trajeto percorrido pela cultura ocidental, se conserva no interior de algumas manifestações artístico-filosóficas da modernidade.

Ao menos três pressupostos filosófico-metafísicos impulsionam a construção das hipóteses filológicas do texto: 1. o mundo possui uma essência, o Unoprimordial (Ur-eines); 2. os fenômenos espaço-temporais e o homem são tão somente aparências, representações, "imagens e projeções artísticas" ONIETZSCHE, 1992, 5, p. 47). deste "verdadeiramente existente" (Ibidem, 4, p. 39) (Wahrhaft-Seiend), o "artista primitivo do mundo" (Ibidem, 5, p. 47); 3. dotado de vontade, o Ser primordial quer "sua redenção [Erlösung] através da aparência" (Ibidem, 4, p. 39). Recorrendo à mitologia, especialmente aos deuses Apolo e Dioniso para associá-los à arte - única via de acesso à verdade do mundo -, Nietzsche reconhece dois impulsos, o apolíneo e o dionisíaco- princípios artísticos que, formulados a partir do dualismo schopenhaueriano vontade e representação, "irrompem da própria natureza" (Ibidem, 2, p. 32) e fazem de todo artista um "imitador" (Ibidem, 2, p. 32) -, como manifestações do Uno-primordial no homem. O apolíneo é um princípio de individuação, intimamente articulado às ideias de medida e consciência de si; o dionisíaco, associado às ideias de hybris e desmedida, é um princípio de união entre as pessoas e de reconciliação entre a natureza e o homem; é o "sentimento místico" (Ibidem, 2, p. 32) de fusão e harmonia - a separação entre homem e natureza é um dos elementos da crítica nietzschiana da cultura - com o Uno-primordial, essência do mundo. O apolíneo, ligado à arte figurativa, é, por analogia, referido ao sonho, lugar em que o homem sente o "profundo prazer" (Ibidem, 1, p. 29) decorrente da contemplação de belas imagens; o dionisíaco, que leva o homem ao prazer oriundo da comunhão com a natureza pela "dissolução" do indivíduo, é associado à embriaguez e à arte musical, não-figurativa.

Para o jovem Nietzsche, o conhecimento da relação entre o Uno-primordial e o mundo fenomênico não é imediatamente acessível. Imerso na vida cotidiana, o indivíduo não vê os fenômenos que se dão no espaço e no tempo como representações do Uno-primordial. Ao contrário, apenas percebe o mundo e a si mesmo como realidades, como algo de fato existente, contraposto à aparência do que vê no sonho que, deste ponto de vista, é "aparência da aparência" (Ibidem, 4., p. 39). Ademais, esse conhecimento não é incondicional; somente em algumas condições, como na dança, sob o efeito de narcóticos e, sobretudo, na música, o homem pode sentir esta verdade fundamental: a realidade de tudo o que ocorre no espaço e no tempo e, inclusive, a sua própria realidade não passam de

\footnotetext{
9 "Em face desses estados artísticos imediatos da natureza, todo artista é um 'imitador' [...]."
} 
representações - manifestações artísticas -- da essência do mundo. Perigoso, o conhecimento da relação entre o querer do Uno-primordial e a efemeridade do individual leva o homem a se defrontar com um grave risco: admitir que é mera aparência do Uno-primordial pode induzi-lo a pensar a vida, afinal decidida por uma vontade soberana e não por sua própria vontade, como destituída de sentido. No entanto, o sentimento de terror daí decorrente - "o subjetivo se esvanece em completo autoesquecimento" (Ibidem, 1, p. 30) - é seguido do "delicioso êxtase", o sentimento de harmonia - "essa harmonia contemplada tão nostalgicamente pelos homens modernos" (Ibidem, 3, p. 38) - com a natureza. A dissolução do indivíduo na natureza, entretanto, não é fiel à vontade do Uno-primordial que quer se redimir ou salvaguardar, manifestando-se empiricamente no mundo dos fenômenos, na aparência. Com o impulso dionisíaco - de "autodestruição e aniquilamento", de comunhão com a natureza - deve se conciliar o impulso apolíneo, capaz de salvar o homem da verdade cruel do sem-sentido da vida através da valorização da aparência, da individuação, do limite, da representação. O apolíneo garante a expressão criativa do Uno-primordial, salva o indivíduo e, como um véu de Maia, deixa-o acreditar na aparência, em sua realidade - na ilusão de sua existência - e na realidade das coisas, escondendo a verdade do mundo para tornar a vida "possível e digna de ser vivida" (Ibidem, 1. p. 29); sem o apolíneo, não seria possível a existência humana dominada pelo dionisíaco impulso à aniquilação.

Ora, se tanto o apolíneo quanto o dionisíaco concretizam os objetivos do Uno-primordial, a solução definitiva da luta não é interessante. Vencendo Apolo o "solar", a "divindade da luz", o "resplendente" (Ibidem, 1, p. 29) -, o homem não toma conhecimento da verdade do mundo; se a vitória é de Dioniso, tal conhecimento impossibilita a vida ou a torna sem sentido. Interessante, então, é a garantia de expressão dos dois impulsos, isto é, dos dois objetivos, conflituosos e contraditórios, do Uno-primordial. Esta garantia - cuja semente estaria na poesia lírica de Arquíloco, na harmonia entre música e linguagem e na canção popular (Volkslied), "espelho musical do mundo" (Ibidem, 6, p. 48), lugar em que a linguagem se empenha em "imitar a música" (Ibidem, 6, p. 49) - é oferecida pelo teatro, pelo "milagre" da tragédia: a despeito da clara tensão entre os dois princípios, a união entre eles se efetiva no "milagre" da tragédia. No palco, o grego é ligado ao Uno-primordial sem, no entanto, deixar-se aniquilar ou destruir. Na tragédia, o "milagre" da reconciliação entre apolíneo e dionisíaco, a representação apolínea do saber dionisíaco: "através de um miraculoso ato metafísico da 'vontade' helênica, apareceram emparelhados um com o outro, e nesse emparelhamento tanto a obra de arte dionisíaca quanto a apolínea geraram a tragédia ática" (Ibidem, 1, p. 27).

Na tragédia, Apolo - deus da luz, da beleza, da medida, das belas formas, da individuação - não vive solitário; antes, acompanha-se de Dioniso, um deus.que, a princípio, estrangeiro, é por ele transfigurado: Apolo transforma o bárbaro dionisíaco e, com a arte, salva o grego do perigo da aniquilação. Conciliação entre apolíneo e dionisíaco, a tragédia permite o "sentimento de unidade" e o consolo metafísico: a vida, apesar de todas as mudanças, "é 
indestrutivelmente poderosa e cheia de alegria" (Ibidem, 7, p. 55); a destruição do herói - "máscara" do "proto-herói Dioniso" (Ibidem, 10, p. 69) -- acaba por revelar que a vida, apesar da destruição e do aniquilamento, permanece soberana em sua unidade originária. Na tragédia, a morte do herói não é a morte da vida: a vida é mais do que individuação. Se arte é transfiguração, especialmente a tragédia leva o homem à percepção da imponderável soberania da vida, "eterna para além de toda a aparência e apesar de todo aniquilamento". A morte do herói trágico, cujo sofrimento retrata o sofrimento de Dioniso, simboliza a volta ao Uno-primordial: se o sofrimento se expressa na individuação, a ruptura da individuação e do Véu de Maia é o retorno à unidade, a reconciliação do homem com a natureza: "Sob a magia do dionisíaco torna a selar-se não apenas o laço de pessoa a pessoa, mas também a natureza alheada, inamistosa ou subjugada volta a celebrar a festa de reconciliação com seu filho perdido, o homem" (Ibidem, 1, p. 31).

Em 1871, discordando da ideia de que a Grécia se caracteriza por uma "serenidade apolínea" e afirmando a excepcional capacidade de o povo grego enfrentar o sofrimento, Nietzsche considera que a arte trágica tem como finalidade a promoção da alegria. Diante do horror inevitável, os gregos inventam a arte trágica como uma espécie de antídoto para experimentar a existência como "fenômeno estético". O mundo grego tem necessidade da tragédia, não para se purificar ou expulsar suas emoções mais densas ou negar a vontade, mas para afirmar a existência, superando o arriscado pessimismo, presente à cruel sabedoria popular de Sileno. Pela tragédia, os gregos celebram a existência, dizem sim até mesmo aos aspectos mais tenebrosos e obscuros do existir, compreendem que dor e sofrimento não merecem ser expurgados ou banidos. Pela invenção do mundo olímpico e da arte trágica, os gregos, extremamente sensíveis ao sofrimento, podem escapar do pessimismo e da destruição. No palco da tragédia ática, a representação apolínea do saber dionisíaco; com ela, os gregos teriam vivenciado a experiência trágica e compreendido o sentido da existência, ao contrário dos modernos. Pela arte, "feiticeira da salvação e da cura" (Ibidem, 7, p. 56), teriam transfigurado a verdade terrível do mundo e tornado a vida possível.

Depois de ocupar-se com o "nascimento da tragédia a partir do espírito da música”, entre os parágrafos 11 e 15, Nietzsche dedica-se a descrever a morte, prematura e lastimável, da arte trágica. Após o período em que, pela transfiguração promovida pela tragédia, os gregos vencem o pessimismo, celebram a vida e experimentam, sem sucumbir, os aspectos mais precários e infames da existência, a Grécia declina e cede espaço ao pensamento antitrágico por excelência, simbolizado, na filosofia, pelas afirmações de Sócrates e, no âmbito da tragédia, pela dramaturgia do "sacrílego" (Ibidem, 10, p. 72). Eurípedes. Com sua "tendência antidionisíaca", Sócrates - ou o modelo de filosofia por ele representado -- abre caminho para a "repressão" da arte e, por conseguinte, para a legitimação da ciência como modo privilegiado de compreensão do mundo. No teatro, Eurípedes encarna o racionalismo socrático; criticando seus antecessores, altera a cena da tragédia quando nela introduz a palavra, o prólogo (Ibidem, 12, p. 81). Com Sócrates e Eurípides, desqualifica-se a tragédia, a estrutura original da cena dá lugar à clareza própria da dialética preconizada por Sócrates. Se a tragédia nasce do 
coro, explicam-se a morte da arte trágica pela exaltação da palavra e o consequente rebaixamento da música, pensa Nietzsche. Com a cumplicidade entre Eurípedes e Sócrates, morre a tragédia, a arte que se consuma na efetiva comunhão entre Apolo e Dioniso.

Bem próximo do ideal de renovação da cultura - alimentado desde Winckelmann, Goethe e Schiller, por exemplo -- $O$ nascimento da tragédia é movido, contudo, pela expectativa de que o trágico reaparecerá no horizonte da cultura alemã. Do parágrafo 16 ao 25, Nietzsche dirige-se a seu tempo para noticiar o renascimento da concepção trágica - o jovem Nietzsche extrapola os limites de qualquer reflexão estética interessada unicamente em pensar a tragédia como gênero literário e se insere no que se pode chamar "filosofia do trágico" --, "a ressurreição do espírito dionisíaco" (Ibidem, 20, p. 121). À época da elaboração de O nascimento da tragédia, a música, de Bach a Beethoven, e a filosofia de Kant e Schopenhauer sugerem o retorno do trágico, o que significa que, na modernidade, necessariamente, já se detêm o ideal socrático de verdade a qualquer preço e o otimismo teórico que assegura a possibilidade do conhecimento. Em especial, é o drama musical de Wagner o lugar em que se conforma a grande chance de "renascimento" do trágico.

\section{III}

A publicação de $O$ nascimento da tragédia, como se sabe, é bastante controversa. ${ }^{10}$ Antes mesmo de o livro vir a público, Nietzsche pressente a iminência de uma acirrada polêmica. Em 23 de novembro de 1871, escreve a Rodhe -- amigo desde os estudos em Leipzig e, como ele, também admirador de Schopenhauer e de Wagner - e se mostra apreensivo com a recepção de suas hipóteses por filólogos, filósofos e músicos. Depois de algumas investidas fracassadas, o texto é finalmente publicado, em 2 de janeiro de 1872, por Ernst Wilhelm Fritzsch, editor de Wagner, a quem o livro é calorosamente dedicado, mas à publicação segue-se um significativo mal-estar. O mundo acadêmico silencia por algum tempo; um tratamento carinhoso vem de Tribschen: ainda em janeiro, tão logo têm em mãos um exemplar, Wagner e a esposa Cosima, com entusiasmo, elogiam o livro. Em 30 de janeiro de 1872, diante do constrangedor silêncio posterior à publicação, Nietzsche, aflito, escreve ao professor Ritschl, um de seus maiores incentivadores, o grande responsável por sua opção pela filologia e por sua entrada na Basileia: "Seu silêncio [...] me intranquiliza um pouco", confessa. No mês seguinte, em 14 de fevereiro, a resposta de Ritschl é um tanto desconcertante: reservado em relação à primeira obra do ex-aluno que muito admirara, o tão estimado mestre e amigo - ressentido por ter recebido o livro da editora ainda em 1871 e não do próprio Nietzsche -, não aprova as hipóteses ali forjadas e, como sempre, despreza a aliança entre filologia, filosofia e arte, ratificando, sutil, mas firme e irredutivelmente, sua antiga inscrição no campo da história, sua confiança no método histórico de investigação filológica de textos antigos: Ritschl incomoda-se sensivelmente com o juízo de Nietzsche sobre a

\footnotetext{
${ }^{10}$ Sobre a polêmica em torno de O nascimento da tragédia, ver MACHADO, 2005.
} 
ciência e com a presença inequívoca tanto da metafísica schopenhaueriana quanto da arte de Wagner; a palavra mais grave e decepcionante, entretanto, está na insinuação de que a concepção nietzschiana de filologia talvez não concorresse para a educação dos jovens, talvez motivasse até mesmo um sentimento de "desdém imaturo" ou descaso pela atividade científica e sequer despertasse na juventude uma "sensibilidade para arte". A insinuação atinge Nietzsche, professor dedicado, preocupado com a formação dos estudantes, com o abandono da "formação humanista" em benefício de uma "formação cientificista", com o futuro das instituições de ensino, com a tarefa da educação na configuração de uma cultura autêntica e superior.

Diante da frustrante atitude do mestre, Rodhe, amigo desde Leipzig, redige, a pedido do próprio Nietzsche, uma resenha - Friedrich Nietzsche (professor regular de filologia clássica na Universidade da Basileia). O nascimento da tragédia no espírito da música. Leipzig, 1872 - que, enviada à revista de filologia Litterarische Zentralblatt com a qual o próprio Nietzsche colaborara, é recusada. Em março, Nietzsche solicita a Rodhe outro texto, agora mais extenso. A nova resenha, bem semelhante à primeira, é levada ao público em 26 de maio pelo jornal de cunho político Norddeutsche Allgemeine Zeitung. Como na anterior, o fiel amigo ressalta a influência da música de Wagner e da filosofia de Schopenhauer e também condena a vinculação irrestrita da filologia ao espírito científico. A provocação mais severa e mordaz ao centauro nietzschiano vem à cena poucos dias depois da veiculação da segunda resenha de Rodhe - $O$ nascimento da tragédia no espírito da música, de Friedrich Nietzsche - no texto Zukunftsphilologie!, escrito por Ulrich von Wilamowitz-Möllendorff, jovem filólogo, também ex-aluno de Pforta, antigo colega de Nietzsche em Bonn. Neste momento, têm início as censuras mais claras e cáusticas, mais cruéis e ofensivas. Wilamowitz-Möllendorff, seguidor de Otto Jahn - filólogo e professor de Bonn --, acusa a fantasia, a "genialidade quimérica", a falta de seriedade e a ignorância de Nietzsche: do ponto de vista do jovem doutor, O nascimento da tragédia é um livro recheado de erros e repleto de deficiências; construído sobre "abstrações estéticas", deixa exposta a incompetência de seu autor que, ao se afastar da ciência, não faz senão deformar a Antiguidade: "a genialidade quimérica e a insolência das afirmações são diretamente proporcionais à ignorância e à falta de amor pela verdade." (MACHADO, 2005, p. 57-58.) Aos seus olhos, "apoiando-se em dogmas metafísicos" (Ibidem, p. 58), Nietzsche não compreende o mundo grego nem a tragédia: "Evidentemente", diz ele, com ironia, "Aristóteles e Lessing não entenderam o drama. O senhor Nietzsche entendeu" (Ibidem, p. 57); equivocado, Nietzsche lê a Antiguidade e os textos antigos a partir de noções modernas e tenta encontrar no passado a prova de suas próprias convicções. Em sua opinião, faltam ao escrito nietzschiano valor científico, objetividade e provas documentais. "Insolente", Nietzsche utiliza-se de um estranho tom, duvida do "método históricocrítico" adotado pela filologia e, portanto, não pode ser apreciado como um autêntico pesquisador: "sua sabedoria, conseguida pela via da intuição, é exposta ora no estilo de um grande pregador religioso, ora em um raisonnement que só tem parentesco com o dos jornalistas" (Ibidem, p. 56). Para o recém-doutor, "o metafísico e apóstolo Nietzsche" (Ibidem, p. 57), de uma "ignorância infantil", cria 
um "ninho de asneiras" (Ibidem, p. 62), é um "mau filólogo e um helenista incapaz" e está no caminho contrário

ao que os heróis da nossa ciência e, enfim, os de toda verdadeira ciência percorreram, sem se deixar afetar por uma presunção a respeito do resultado final, honrando apenas a verdade de avançar de conhecimento em conhecimento, de compreender cada fenômeno histórico somente a partir das condições da época em que eles se desenvolveram e de ver sua justificativa na própria necessidade histórica. De fato, esse método histórico-crítico, pelo menos em princípio um bem comum da ciência, contrapõe-se diretamente a uma maneira de consideração que, ligada a dogmas, tem sempre que buscar a confirmação de tais dogmas. O senhor Nietzsche também não poderia escapar a essa contraposição. Sua saída é denegrir o método histórico-crítico, injuriar toda concepção estética que se afasta da sua, atribuir à época em que a filologia se elevou na Alemanha a uma altura nunca imaginada, sobretudo com Gottfried Hermann e Karl Lachmann, um total desconhecimento dos estudos antigos' (Ibidem, p. 58).

Para ele, Nietzsche não leu Winckelmann que, no século XVIII, configurara novos critérios para a história da arte e, assim, influenciara tanto a literatura quanto a filosofia alemãs posteriores:

Certamente ele escreve só para aqueles que, como ele, nunca leram Winckelmann. Quem aprendeu com Winckelmann a ver a essência da arte helênica unicamente no belo se afastará, com repugnância, do simbolismo universal da dor original, da alegria com o aniquilamento do indivíduo, da alegria da dissonância. Quem aprendeu com Winckelmann a conceber historicamente a essência da beleza segundo suas diferentes manifestações em épocas diversas, mais ainda, a fazer justiça àquela duplicidade da beleza que Winckelmann enuncia de modo tão magistral, - quem aprendeu com ele, enfim, jamais falaria de uma degeneração surpreendente do espírito helênico' (Ibidem, p. 58-59).

Nietzsche "não conhece Homero, ou no máximo o conhece como aquele mendigo cego mencionado no agón Homéroukaì Hesiódu” (Ibidem, p. 62), provoca Wilamowitz; "não conhece Eurípedes" (Ibidem, p. 73), "ameaça esse poeta" (Ibidem, p. 71), "afirma destemidamente que Eurípedes é partidário do princípio socrático: virtude é saber."11 Em suma, na contracorrente do espírito científico, ao revisitar os gregos, Nietzsche deturpa a Grécia e, mais grave para um filólogo, um cientista, demonstra preferências particulares ao invés de se concentrar unicamente na palavra e nas minúcias e detalhes dos textos antigos em prol da objetividade. Com tudo isso, o professor Nietzsche ofende Pforta, a escola-

${ }^{11}$ Cf. MACHADO, op. cit., p. 72-73: "O verdadeiro motivo pelo qual o senhor Nietzsche estabelece a ligação entre esses dois homens [Eurípedes e Sócrates] se encontra no ódio ardente que alimenta contra ambos." 
mãe: "Que ofensa, senhor Nietzsche, à nossa mãe Pforta!" (Ibidem, p. 62). "Ah, estou cansado de corrigir o exercitium do senhor Nietzsche" (Ibidem, p. 75). Nas linhas finais do artigo, a hostilidade e a virulência são extremas; aludindo a uma passagem do livro nietzschiano, diz ele: "cumpra a palavra, pegue o tirso em suas mãos, vá da Índia para a Grécia à vontade, mas desça da cátedra na qual deveria ensinar ciência" (Ibidem, p. 78). ${ }^{12}$ Em 1879, Nietzsche "descerá da cátedra" e deixará o exercício do magistério, mas por outros motivos bem distintos!

Rodhe se aborrece com o tom agressivo, irônico e debochado do texto de Wilamowitz - Filologia do futuro! Uma réplica a O nascimento da tragédia de Fr. Nietzsche, professor de filologia clássica na Basiléia ${ }^{13}$ - que, na verdade, nem é uma réplica como assegura o título, mas um ataque, curiosa e estranhamente, passional, bem destoante do rigor científico por ele mesmo requerido. De novo, Rodhe escreve em favor do amigo: com a aquiescência de Nietzsche, redige uma carta aberta a Wagner, Filologia retrógrada. Esclarecimentos acerca do panfleto "Filologia do futuro!", publicado pelo doutor em filologia Ulrich Von WilamowitzMöllendorff. Carta aberta de um filólogo a Richard Wagner. Antes que viessem à tona as palavras de Rodhe, Wagner - que recebera de Nietzsche o panfleto de Willamowitz em 9 de junho e também se sentira por ele agredido - escreve uma Carta aberta a Friedrich Nietzsche, publicada no Nordddeutsche Allgemeine Zeitung, no dia 23 do mesmo mês, e reprova a filologia vigente em defesa do jovem professor: "é evidente que a filologia atual não exerce influência alguma sobre a situação da cultura alemã em geral" (MACHADO, op. cit., p. 82). Wagner concorda com Rodhe: com $O$ nascimento da tragédia, Nietzsche descortina um novo caminho para a filologia. Diferente do que talvez se esperasse, a carta de Wagner acentua a desavença entre Nietzsche e os filólogos. Em carta a Nietzsche, de 2 de julho, Ritschl, também indignado, rejeita o texto de Wagner bem como o artigo do próprio Wilamowitz: o confronto com Wilamowitz não deveria investir contra a filologia, propriamente. O texto de Rodhe, Filologia retrógrada (Afterphilologie), um ataque pessoal a Wilamowitz, depois de ser negado por Teubner, editor de filologia, é finalmente publicado em 15 de outubro, por Fritsch, o que parece endossar a associação, presente nos textos de 1870 e em $O$ nascimento da tragédia e renegada pelos filólogos, entre filologia e arte. Nietzsche gosta do artigo de Rodhe, que aponta o "ataque totalmente frívolo do doutor em filologia" (Ibidem, p. 98), como se pode ler na carta de 25 de outubro, mas, em 1 de novembro, Rodhe lhe escreve, contrariado com a entonação excessivamente rude impressa em seu próprio artigo. Contra Rodhe, e não apenas contra Nietzsche,

\footnotetext{
${ }^{12}$ Em 08 de Junho, mais uma vez, Nietzsche escreve a Rodhe e dá a entender que os ataques do antigo colega, sua severidade e ironia talvez sejam motivados por uma questão pessoal - embora Wilamowitz diga o contrário -- que remonta ao célebre desentendimento, transcorrido em 1864, entre Otto Jahn e Ritschl, então colegas em Bonn, desentendimento que acabara por forçar Ritschl a se transferir, em 1865, para Leipzig. Ainda que identifique o caráter polêmico de seu livro, por algum tempo, Nietzsche imagina que a virulência de Wilamowitz pudesse ser justificada por essa remota divergência entre os antigos mestres ou até mesmo por uma espécie de concorrência entre Bonn e Leipzig, dois grandes centros de pesquisas filológicas. Nietzsche não se engana totalmente: de fato, Wilamowitz havia se incomodado com a recomendação de Nietzsche por Ritschl para a cadeira de filologia clássica na Basileia. Mais tarde, em suas memórias, admite que não conseguira desculpar Nietzsche que, a seu ver, por interesse pessoal, escolhera Ritschl em detrimento de Jahn.
} 
Wilamowitz publica, em fevereiro de 1873, Filologia do futuro! (Segunda parte). Uma réplica às tentativas de salvação de O nascimento da tragédia de Friedrich Nietzsche. A esta altura desinteressados de discussões e conflitos, Nietzsche e Rodhe retiram-se em silêncio.

IV

Wilamowitz, o jovem doutor em filologia, tem razão: se, em $O$ nascimento da tragédia, Nietzsche dirige-se ao passado para pensar o presente e reveste sua atividade filológica e sua leitura da Antiguidade por uma concepção filosófica moderna, se, afinal, põe sob suspeita a autonomia da filologia quando a associa à filosofia e à arte, se questiona a concepção corrente de ciência e de objetividade e toma partido de um tipo de cultura ao acusar Sócrates e Eurípedes como responsáveis pela morte da tragédia e pela separação entre filosofia e arte, se coloca nas notas da música de Wagner a tarefa de deixar renascer o trágico, está, de certa forma, no caminho inverso ao percorrido por aqueles que ele, Wilamowitz, nomeia "heróis" da ciência e, de fato, não pode ser reconhecido como um autêntico pesquisador, caso se entenda que o valor de uma pesquisa se define pela suposta "pureza" de seus passos e suas conclusões e por sua liberdade em relação à criação artística. A agressividade de seus ataques é compreensível: plenamente alinhado a uma determinada concepção de ciência, ${ }^{14}$ Wilamowitz não pode admitir que um filólogo se desgarre do método histórico, desconfie da independência da ciência e exponha preferências pessoais; não pode concordar com a valorização da arte como uma espécie de alternativa à hegemonia da ciência nem com a solução filosófica e estética dada por Nietzsche à tragédia. É possível que tenha percebido que nas linhas de O nascimento da tragédia já se desenhava, em terreno distinto, não só uma nova forma de pensar a atividade filológica e, além disto e por isto mesmo, uma nova forma de conceber a ciência, o conhecimento, a verdade e a história, a relação entre passado e presente, mas a reação, tão furiosa, era previsível: o jovem doutor não poderia aceitar uma filologia atrelada, visceralmente, à filosofia e à arte.

\footnotetext{
${ }^{14}$ Como não poderia deixar de ser, o jovem Nietzsche tem conhecimento de que, depois de Wolf, instituem-se diferentes grupos no terreno da filologia que, apesar de manterem pontos em comum, têm divergências políticas e acabam por se afastar do ideal wolfiano, o que significa que, em sua opinião, entre Wolf e a filologia predominante no século XIX, há uma distância bastante razoável. Ao menos dois podem ser lembrados: o grupo integrado por Otto Jahn e Wilamowitz; outro, representado por Ritschl. Enquanto o primeiro defende a necessidade de atenção estrita aos "dados históricos" da Antiguidade como requisito imperioso à conquista da objetividade científica, o outro reconhece a filologia como ciência, mas abre espaço para a consideração da "personalidade" daquele que pesquisa. Na aula inaugural, já dissera: "há [...] numerosas e altamente variadas inimizades entre determinadas orientações da filologia; combates a morte de filólogos contra filólogos desavenças de natureza puramente doméstica, provocadas por uma inútil disputa de hierarquias e ciumeiras recíprocas, mas sobretudo pela diversidade já acentuada, pela inimizade dos dois impulsos básicos reunidos mas não fundidos sob o nome de filologia. [...] Para o indivíduo não há nenhuma salvação da discórdia acima descrita, mas o que nós afirmamos, a bandeira que erguemos, é o fato de que a filologia clássica em sua grande totalidade nada tem a ver com estas lutas e aflições de seus singulares jovens."
} 
Parece razoável a ponderação de que, além de toda a sua importância para as discussões estéticas contemporâneas, $O$ nascimento da tragédia também nos coloca diante da inquietação de Nietzsche com o ensino e a educação de seu tempo: inseridas no programa mais amplo de crítica da cultura alemã, as ressalvas à filologia parecem ressoar na crítica mais explícita da educação, presente de modo mais claro em cartas escritas nesse período de juventude, nas cinco conferências Sobre o futuro dos nossos estabelecimentos de ensino e, um pouco mais tarde, nas Considerações extemporâneas, em especial, na Terceira, Schopenhauer como educador: Ou, inversamente, as conferências e a Terceira extemporânea parecem expressar sentimentos mais antigos já sedimentados. Se em $O$ nascimento da tragédia essa reflexão sobre a educação não aparece claramente, no entanto, é provável que as objeções à filologia e à ciência que se distanciam da filosofia e da arte sejam tributárias da crítica exposta nesses textos e na correspondência, uma vez que, desde o início de sua atividade docente, Nietzsche manifesta sua inquietação com o ensino e com o meio universitário. Se o afastamento da filologia de seus contemporâneos, a volta aos gregos como modelo interpretativo da modernidade alemã e as hipóteses filológicas sobre o nascimento e a morte da tragédia demonstram sua precoce recusa de uma cultura doente e fraca em que predomina uma determinada concepção de ciência em detrimento da arte - recusa que será sofisticada ao longo de sua trajetória filosófica -, pode-se supor que demonstram ainda a rejeição de um tipo de educação que não só privilegia a produção científica e a história como busca da verdade, mas também separa estética e atividade científica, conhecimento e vida; um tipo de educação que, por isto mesmo, não pode concorrer para a conformação de uma cultura superior.

Nas conferências, pronunciadas à época do início da polêmica em torno de O nascimento da tragédia, entre janeiro e março de 1872, é bem evidente a preocupação de Nietzsche com os rumos trilhados pelas instituições pedagógicas da Alemanha e com a relação entre a educação dos jovens e a constituição de uma cultura superior. A educação alemã de seu tempo, diz ele, é alimentada por duas tendências: uma proclama a "extensão" e "ampliação", outra, a "redução" da cultura. Ambas se apresentam nos estabelecimentos de ensino alemão, na escola primária, no ginásio, na escola técnica e na universidade. Antagônicas à primeira vista, mas cúmplices nos "resultados", no fundo, as duas são nocivas: enquanto uma requer a democratização da cultura e facilita o aumento do número de instituições educacionais, a outra obriga a cultura a deixar de lado seus propósitos mais "nobres" e a se transformar em serva do Estado. A primeira, exaltando a utilidade e objetivando o aumento do lucro e do "ganho de dinheiro" - supostos promotores da felicidade -- dá sinais de que atende aos "dogmas da economia política" (nationalökonomischen Dogmen); a segunda, louvando a especialização, concorre para o aniquilamento da cultura. Ambas abrigam uma concepção limitada de cultura e atestam a "pobreza pedagógica" da Alemanha.

Atento, Nietzsche reconhece que as transformações sociais, econômicas e políticas porque passara a Alemanha cederam lugar a uma determinada noção de cultura e de educação que acabou por levar os alemães à "miséria cultural". A educação de seu tempo, diz nas Conferências, é um solo fértil para o enraizamento 
do "filisteísmo cultural". Obediente aos interesses da política e da economia e orientada para a "uniformidade", a profissionalização e a especialização, a educação está nas mãos de "filisteus da cultura" (Bildungsphilister) que, por confundirem cultura com erudição, representam um sério risco à formação da juventude. A instituição de uma cultura autêntica exige, não a "uniformidade" de opiniões, mas a "unidade de estilo". A "uniformidade de opiniões" dá à Alemanha a ilusão de ser uma cultura superior, quando, em realidade, pensa Nietzsche, nela já se encontram instaladas a mediocridade e a barbárie. Para o jovem professor, a educação não pode ser reduzida à profissionalização nem à especialização, não pode ser escravizada pelos caprichos da política estatal e/ou do mercado nem pode ser reduzida à erudição ou à profissionalização e à especialização. Se profissionalização e especialização não são dispensáveis, no entanto, não são sinônimos de cultura nem podem ser o fim privilegiado da pedagogia. O interesse soberano da educação não pode ser simplesmente promover a ascensão a uma profissão em atenção a critérios utilitaristas, pragmáticos e comerciais. A preocupação com a profissão e a adesão irrestrita aos ideais do Estado e da economia não são estímulos à imprescindível autonomia do pensamento dos educandos e à imperiosa capacidade de crítica e de criação.

A crítica radical da cultura alia-se, no jovem Nietzsche, a um projeto pedagógico para a Alemanha, projeto com o qual poderiam colaborar a filologia e a história caso não se acorrentassem a argumentos destinados a provar a verdade incondicional e intransponível de suas análises do mundo antigo e adotassem outra forma de entrelaçar passado e presente. Com sua proposta de ampliação do âmbito da investigação filológica, Nietzsche parece dizer que a filologia, caso fosse concebida de forma diversa da que reina na academia, isto é, se permitisse uma forte aliança com a filosofia e com a arte e, sobretudo, se, na volta ao passado, firmasse um compromisso com o presente e com o futuro, poderia ser muito mais valiosa para a formação dos jovens e para a cultura. Talvez não seja preciso esperar pela Segunda extemporânea - que condena o "excesso de sentido histórico" da modernidade e o diagnostica como "doença" - para concluir que, para o Nietzsche de $O$ nascimento da tragédia, a volta ao passado - procedimento próprio da filologia -- só tem razão de ser em função do presente.

Para além da importância de $O$ nascimento da tragédia para a discussão estética contemporânea, esta talvez seja mais uma contribuição da crítica à filologia e à história: o saber - científico, filológico, histórico - tem valor quando tem valor para a vida. As palavras de Goethe, divisa do texto da Segunda extemporânea, são emblemáticas: "odeio tudo aquilo que apenas me instrui, sem aumentar ou estimular minha ação" (NIETZSCHE, 2017, p. 29). Não é assim que, na opinião de Nietzsche, pensa grande parte dos filólogos do século XIX: obcecados pelo desejo de verificar as filigranas dos textos antigos, seus contemporâneos não indagam a si próprios: qual é, efetivamente, a relevância do mundo grego para o mundo moderno? a pesquisa detalhada de textos antigos é suficientemente fértil para elevar a cultura moderna já que a erudição só consegue instituir uma "cultura artificial"? a filologia, como decifração de textos antigos, pode auxiliar a cultura e, em particular, a formação dos jovens? que valor pode ter para a vida a recuperação 
histórica de textos antigos, caso não se veja no retorno ao passado a chance de problematizar o presente e olhar para o futuro? que tipo de vida pode promover o filólogo desprovido de uma visão filosófica ou um historiador "coveiro do presente"?

Em 1871-1872, Nietzsche já está na contramão do caminho traçado por seus contemporâneos ao reclamar um novo tipo de cultura para o qual são indispensáveis uma nova concepção de ciência - seja ela a filologia, a história ou outra qualquer - e uma outra educação capaz de enraizar em seus estabelecimentos de ensino o cuidado com a formação do estudante, com o que denomina "cultivo de si".

A despeito da necessidade de também expor à crítica ao menos alguns aspectos da crítica nietzschiana da filologia e da educação, pode-se, todavia, reconhecer que, se Wilamowitz e Ritschl não puderam prever o alcance das ponderações sobre a filologia e a história, Nietzsche, inatual, talvez não pudesse imaginar que, senão todas, muitas de suas advertências sobre a educação e a cultura permanecessem tão atuais tanto tempo depois!

\section{REFERÊNCIAS BIBLIOGRÁFICAS}

MACHADO, Roberto (org.). Nietzsche e a polêmica sobre O nascimento da tragédia. Tradução e notas: Pedro Süssekind. Rio de Janeiro: Zahar, 2005.

NIETZSCHE. O nascimento da tragédia ou Helenismo e pessimismo. Tradução, notas e posfácio: J. Guinsburg. São Paulo: Companhia das Letras, 1992.

- A gaia ciência. Tradução, notas e posfácio: Paulo César de Souza São Paulo: Companhia das Letras, 2001.

Homero e a filologia clássica. Tradução, apresentação e notas: Juan A. Bonaccini. Princípios, Natal, vol. 13, n. 19, jan./dez., 2006.

- Sobre a utilidade e a desvantagem da história para vida. Segunda consideração extemporânea. Organização e tradução: André Itaparica. São Paulo: Hedra, 2017.

Sämtliche Werke. Kritische Studienausgabe. 15 v. Berlim/Munique: Walter de Gruyter, 1980.

Stämtliche Briefe. Kritische Studienausgabe. 8 v. Munique/Berlim/Nova York: Walter de Gruyter, 1988. 